\title{
P Protein
}

National Cancer Institute

\section{Source}

National Cancer Institute. P Protein. NCI Thesaurus. Code C131356.

P protein ( $838 \mathrm{aa}, \sim 93 \mathrm{kDa}$ ) is encoded by the human OCA2 gene. This protein plays a role in melanogenesis and transmembrane transport of tyrosine and hydrogen ions. 